Rev. Bras. Saúde Prod. Anim., Salvador, v.15, n.4, p.881-896 out./dez., 2014 http://www.rbspa.ufba.br ISSN 15199940

\title{
Inclusion of glutamine associated with glutamic acid in the diet of piglets weaned at 21 days of age
}

\author{
Inclusão de glutamina associada com ácido glutâmico na dieta de leitões desmamados \\ aos 21 dias de idade
}
TEIXEIRA, Alexandre de Oliveira ${ }^{1 *}$; NOGUEIRA, Eduardo Terra ${ }^{2}$; KUTSCHENKO, Marianne $^{2}$; ROSTAGNO, Horacio Santiago ${ }^{3}$; LOPES, Darci Clementino ${ }^{3}$

\author{
${ }^{1}$ Universidade Federal de São João del-Rei, Departamento de Zootecnia, São João del-Rei, Minas \\ Gerais, Brasil. \\ ${ }^{2}$ Ajinomoto do Brasil, São Paulo, Brasil. \\ ${ }^{3}$ Universidade Federal de Viçosa, Departamento de Zootecnia, Viçosa, Minas Gerais, Brasil. \\ *Endereço para correspondência: alexandre_teixeira@ufsj.edu.br
}

\section{SUMMARY}

The effects of dietary inclusion levels of the association of glutamine with glutamic acid (AminoGut: $\mathrm{AmG}$ ) on the performance, gastrointestinal morphophysiology, and diarrhea incidence of piglets weaned at 21 days of age were evaluated. In the experiment, 120 piglets with 6.24 $\pm 1.00 \mathrm{~kg}$ initial weight were distributed according to a randomized block experimental design into five treatments with six replicates of four animals each. The following treatments were applied: negative control diet ( $0 \% \mathrm{AmG}) ; 0.5 \% \mathrm{AmG}$; $1.0 \% \mathrm{AmG} ; 1.5 \% \mathrm{AmG}$; positive control diet $(0 \%$ AmG, 4\% inclusion of porcine plasma). The inclusion of $1.0 \% \mathrm{AmG}$, as compared to the positive control diet, improved weight gain, feed intake and feed conversion ratio. The lowest diarrhea score was observed when $1.0 \%$ AmG was included, whereas the best villus height and villus:crypt ratio were obtained with the inclusion of $0.82 \%$ AmG. Villus height, crypt depth, and villus:crypt ratio values obtained with $1.0 \% \mathrm{AmG}$ were similar to those obtained with the positive control diet, except in the period of 21 to 28 days, when the diet with $1.0 \%$ AmG promoted higher villus:crypt ratio. The supplementation of 0.5 and $1.0 \%$ AmG affected organ weights, and reduced digestive content $\mathrm{pH}$ in the pylorus and in the ileum relative to the positive control diet. The dietary supplementation of $1 \%$ glutamine associated with glutamic acid improves the performance and the morphophysiology of piglets weaned at 21 days of age.

Keywords: amino acids, diarrhea, nutrition, intestinal mucosa, villus

\section{RESUMO}

Avaliou-se o efeito dos níveis de inclusão da associação de glutamina e ácido glutâmico (AminoGut: AmG) nas rações sobre o desempenho, morfo-fisiologia gastrintestinal e incidência de diarréia de leitões desmamados aos 21 dias de idade. Foram utilizados 120 leitões com peso inicial de $6,24 \pm 1,00 \mathrm{~kg}$, distribuídos em delineamento de blocos casualizados, distribuídos de acordo com o peso, cinco tratamentos, seis repetições e quatro leitões por unidade experimental. Os tratamentos foram: controle negativo $(0 \% \mathrm{AmG}) ; 0,5 \% \mathrm{AmG} ; 1,0 \% \mathrm{AmG}$; 1,5\% AmG; controle positivo $(0 \% \mathrm{AmG}, 4 \%$ de inclusão de plasma suíno). A inclusão de $1,0 \%$ de AmG, quando comparada com a dieta controle positivo, melhorou o ganho de peso, consumo de ração e conversão alimentar. O menor índice de diarréia foi observado com $1,0 \%$ de AmG. Os melhores resultados de altura de vilosidade intestinal e relação vilosidade:cripta foram obtidos com $0,82 \%$ de AmG. Altura de vilosidade, profundidade de cripta e relação vilo:cripta com $1,0 \%$ de AmG foram similares aos obtidos com a dieta controle positivo, no entanto, a relação vilo:cripta foi maior para a dieta $1,0 \%$ de $\mathrm{AmG}$ no período de 21 a 28 dias. A suplementação de 0,5 e $1,0 \%$ de AmG alterou o peso dos órgãos e reduziu o $\mathrm{pH}$ da região pilórica e do íleo do intestino delgado em relação ao controle positivo. A suplementação de $1 \%$ de glutamina associada ao ácido glutâmico na ração melhora o desempenho e a morfo-fisiologia gastrintestinal de leitões desmamados aos 21 dias de idade.

Palavras-chave: aminoácidos, diarréia, nutrição, mucosa intestinal, vilosidade 


\section{INTRODUCTION}

Glutamine and glutamic acid are the most abundant free $\alpha$-amino acids in the body of mammals and comprise between 5 and $15 \%$ of dietary protein. These amino acids, previously considered as conditionally essential, have been recently classified as essential in hypercatabolic states, such as weaning. In addition, there are evidences that the supplementation of the association of glutamine with glutamic acid in diets for weaned piglets optimizes growth rate and improves animal performance (WATFORD et al., 2011).

Glutamine is the most important energy substrate for fast-dividing cells, such as enterocytes and lymphocytes, as well as for other cell types, including macrophages and kidney cells, supplying ATP for intra-cellular protein turnover, nutrient transport across the cell membrane, cell growth and migration, and maintenance of cell integrity (LI et al., 2007).

Increases the expression of genes related to nutrient metabolism and cell survival (CURI et al., 2005). These genes include ornithine decarboxylase (key enzyme for the synthesis of polyamines that stimulate the synthesis of DNA and protein), heat-shock protein that protects cells from death, and nitric oxide synthase that converts arginine in nitric acid, which signals regulated virtually every cell function (WU, 2011).

Glutamine may be an essential feed component for the maintenance of intestinal integrity and of intestinal mucosa permeability, improving nutrient absorption (YI et al., 2005) and consequently animal performance. The predominance of glutamine in milk of sows suggests that this aminoacid presents a relevant role in the development and the performance of piglets (ABREU \& DONZELE, 2008). The use of glutamine in piglet diets has shown positive results in terms of maintenance of intestinal integrity, particularly villi height and crypt depth, during weaning, and its effect on the recovery of the intestinal mucosa after injury has been investigated, as this amino acid is the main metabolite feeding enterocytes (PIVA, 2001).

The spray-dried porcine plasma has been considered a effective source of proteins in the diet of piglets, being demonstrate positive effect in the weight gain and feed intake (BIKKER et al., 2004).

The objective of the present study was to evaluate the performance, the incidence of diarrhea, and the gastrointestinal morphology and physiology of piglets weaned at 21 days of age and fed diets with different inclusion levels of glutamine associated to glutamic acid.

\section{MATERIALS AND METHODS}

In the experiment, 120 male and female piglets, weaned at 21 days of age and with an initial body weight of $6.24 \pm$ $1.00 \mathrm{~kg}$, were distributed according to a randomized block design, consisting of five treatments, with six replicates of four piglets each. The criteria for block formation were sow farrowing date, relatedness, average piglet weight, and sex.

-The glutamine and glutamic acid source was the commercial product AminoGut (AmG), which is composed of a minimum of $95 \%$ glutamine + glutamic acid. 
-The five experimental treatments were: negative control diet $(0 \%$ AmG, $0 \%$ porcine plasma inclusion); $0.5 \% \mathrm{AmG}$; 1.0\% AmG; $1.5 \%$ AmG; positive control diet $(0 \%$ AmG, $4 \%$ porcine plasma inclusion).

-The experimental diets contained equal energy, lysine, calcium, and phosphorus levels, and were formulated to supply the nutritional requirements of piglets in the phase, according to the recommendations of Rostagno et al. (2005). The ingredient composition and the nutritional values of the experimental diets are presented in Table 1.

After weaning, piglets were housed in a masonry nursery room, with wood ceiling, concrete floor, ventilation flaps, equipped with suspended metal cages with expanded plastic floor and wire mesh sides, semi-automatic feeders and nipple drinkers. Water and solid feed were provided ad libitum.

During the experimental period, ventilation and environmental temperature were controlled by opening or closing the ventilation flaps and heating lamps. Environmental temperature was measured using maximum-minimum thermometers, and air relative humidity using dry and wet bulb thermometers placed in the middle of the room outside the cages, at the piglet's body height.

The live performance parameters average daily weight gain, average daily feed intake, feed conversion ratio and diarrhea score were evaluated for the periods of 21 to 28 and 21 to 42 days of age.

Piglets were daily observed to evaluate fecal texture. The following score was used: 1 - dry and firm stools; 2 - stools with normal texture; 3 - soft, nondiarrhea stools; 4 - watery feces, characteristic of diarrhea. It was evaluated the score of the four piglets of the box.

On days 21, 28, 35 and 42, the lightest piglet of each experimental unit was stunned, euthanized, dehaired, and eviscerated. Empty carcass, liver, kidneys, and small intestine were weighed. Stomach content $\mathrm{pH}$ was measured in the cardia and pylorus region, and intestinal content $\mathrm{pH}$ was measured in the duodenum and ileum, using an electric $\mathrm{pHmeter}$.

Intestinal segments of approximately $1.0 \mathrm{~cm}$ were collected at $20 \mathrm{~cm}$ from the pylorus, medial section of the small intestine, and $20 \mathrm{~cm}$ from the ileocecal valve, corresponding to the duodenum, jejunum and ileum, respectively. The segments were then opened by the mesenteric edge, extended by the serosa, and fixed in Bouin solution for 24 hours, after which they were rinsed and preserved in alcohol at $70 \%$ until analysis.

The small intestine segments were submitted to the Histology Laboratory of the Department of Animal Biology of the Federal University of Viçosa, where they were dehydrated in alcohol, cleared in xylol, and embedded in paraffin. Sections measuring $7 \mu \mathrm{m}$ were stained by the hematoxylin-eosin method. Villus height and crypt depth were measured using a microscope coupled to the image analyzer "IMAGE-PRO PLUS 1.3.2", at 40x magnification; 30 villi and 30 crypts, well-oriented and longitudinally cut, were measured in each section. 
Rev. Bras. Saúde Prod. Anim., Salvador, v.15, n.4, p.881-896 out./dez., 2014 http://www.rbspa.ufba.br ISSN 15199940

Table 1. Ingredient composition and nutritional values of the experimental diets

\begin{tabular}{|c|c|c|c|c|c|}
\hline \multirow[b]{2}{*}{ Ingredients } & \multicolumn{5}{|c|}{ Experimental diets } \\
\hline & $\begin{array}{l}\text { Negative } \\
\text { control }\end{array}$ & $\begin{array}{l}0.5 \% \\
\mathrm{AmG}\end{array}$ & $\begin{array}{c}1.0 \% \\
\mathrm{AmG}\end{array}$ & $\begin{array}{l}1.5 \% \\
\text { AmG }\end{array}$ & $\begin{array}{l}\text { Positive } \\
\text { control }\end{array}$ \\
\hline Corn & 22.741 & 22.741 & 22.741 & 22.741 & 28.786 \\
\hline Pre-cooked corn & 15.000 & 15.000 & 15.000 & 15.000 & 15.000 \\
\hline Soybean meal $45 \%$ & 23.958 & 23.958 & 23.958 & 23.958 & 17.085 \\
\hline Micronized soybeans & 10.000 & 10.000 & 10.000 & 10.000 & 10.000 \\
\hline Powdered whey & 7.000 & 7.000 & 7.000 & 7.000 & 7.000 \\
\hline Powdered whole milk & 7.000 & 7.000 & 7.000 & 7.000 & 7.000 \\
\hline Sugar & 6.000 & 6.000 & 6.000 & 6.000 & 6.000 \\
\hline Plasma & - & - & - & - & 4.000 \\
\hline Starch & 2.000 & 1.500 & 1.000 & - & - \\
\hline Glutamine + glutamic acid & - & 0.500 & 1.000 & 1.500 & - \\
\hline Fumaric acid & 1.500 & 1.500 & 1.500 & 1.500 & 1.500 \\
\hline Soybean oil & 1.012 & 1.012 & 1.012 & 1.012 & 0.218 \\
\hline Limestone & 0.639 & 0.639 & 0.639 & 0.639 & 0.604 \\
\hline Dicalcium phosphate & 1.774 & 1.774 & 1.774 & 1.774 & 1.872 \\
\hline Salt & 0.284 & 0.284 & 0.284 & 0.284 & 0.074 \\
\hline L-lysine $\mathrm{HCl}(79 \%)$ & 0.324 & 0.324 & 0.324 & 0.324 & 0.225 \\
\hline DL-methionine (99\%) & 0.227 & 0.227 & 0.227 & 0.227 & 0.153 \\
\hline L-threonine & 0.140 & 0.140 & 0.140 & 0.140 & 0.082 \\
\hline Vit.+additives premix ${ }^{1}$ & 0.300 & 0.300 & 0.300 & 0.300 & 0.300 \\
\hline Mineral premix $^{2}$ & 0.100 & 0.100 & 0.100 & 0.100 & 0.100 \\
\hline \multicolumn{6}{|c|}{ Calculated nutritional composition } \\
\hline Digestible energy, kcal/kg & 3700 & 3700 & 3700 & 3700 & 3700 \\
\hline Metabolizable energy, $\mathrm{kcal} / \mathrm{kg}$ & 3501 & 3501 & 3501 & 3501 & 3501 \\
\hline Protein, $\%$ & 21.00 & 21.00 & 21.00 & 21.00 & 21.00 \\
\hline Total lysine, $\%$ & 1.500 & 1.500 & 1.500 & 1.500 & 1.500 \\
\hline Dig. lysine\% & 1.375 & 1.375 & 1.375 & 1.375 & 1.375 \\
\hline Total methionine + cystine, $\%$ & 0.870 & 0.870 & 0.870 & 0.870 & 0.870 \\
\hline Total methionine, $\%$ & 0.561 & 0.561 & 0.561 & 0.561 & 0.561 \\
\hline Total threonine, $\%$ & 0.975 & 0.975 & 0.975 & 0.975 & 0.975 \\
\hline Total tryptophan, $\%$ & 0.269 & 0.269 & 0.269 & 0.269 & 0.269 \\
\hline Calcium, $\%$ & 0.900 & 0.900 & 0.900 & 0.900 & 0.900 \\
\hline Available phosphorus, $\%$ & 0.516 & 0.516 & 0.516 & 0.516 & 0.516 \\
\hline Sodium, $\%$ & 0.220 & 0.220 & 0.220 & 0.220 & 0.220 \\
\hline
\end{tabular}

${ }^{\mathrm{T}}$ Content $/ \mathrm{kg}$ feed: vitamin $\mathrm{A}-10,000 \mathrm{IU}$; vitamin $\mathrm{D}_{3}-1,500 \mathrm{IU}$; vitamin $\mathrm{E}-30 \mathrm{IU}$; vitamin $\mathrm{K}_{3}-2 \mathrm{mg}$; vitamin $B_{1}-2 \mathrm{mg}$; vitamin $B_{2}-5 \mathrm{mg}$; vitamin $B_{6}-3 \mathrm{mg}$; vitamin $B_{12}-30 \mathrm{mcg}$; folic acid $-0.8 \mathrm{mg}$; nicotinic acid - $30 \mathrm{mg}$; pantothenic acid $-12 \mathrm{mg}$; biotin $-0.100 \mathrm{mg}$; selenium - $0.300 \mathrm{mg}$; choline chloride $60 \%, 500 \mathrm{mg}$; BHT, $0.100 \mathrm{mg}$; virginiamycin, $20 \mathrm{mg}$; carbadox, $40 \mathrm{mg}$

${ }^{2}$ Content $/ \mathrm{kg}$ feed: iron - $100 \mathrm{mg}$; copper $-10 \mathrm{mg}$; cobalt $-1 \mathrm{mg}$; manganese $-40 \mathrm{mg}$; zinc $-100 \mathrm{mg}$; iodine $-1.5 \mathrm{mg}$

The present data were submitted to tests in order to evaluate the normality, employing Shapiro-Wilk at 5\% probability level. Performance, carcass, organs, diarrhea, intestinal morphology and $\mathrm{pH}$ were compared using the test of Dunnett, comparing the positive control (plasma) treatment with the other 
Rev. Bras. Saúde Prod. Anim., Salvador, v.15, n.4, p.881-896 out./dez., 2014 http://www.rbspa.ufba.br ISSN 15199940

treatments. Performance and intestinal morphology data of the treatments with $0, \quad 0.5, \quad 1.0$ and $1.5 \%$ glutamine + glutamic acid inclusion levels were submitted to regression analysis at 5\% probability level.

\section{RESULTS AND DISCUSSION}

Average maximum and minimum temperatures observed during the experimental period were $27.23 \pm 1.18$ and $24.68 \pm 1.87{ }^{\circ} \mathrm{C}$ respectively, and average air relative humidity was 73.06 $\pm 5.43 \%$.

During the period of 21 to 28 days of age, the piglets fed the diet with $1.0 \%$ glutamine + glutamic acid (AmG) obtained higher $(\mathrm{P}<0.05)$ daily weight gain (DWG) and those fed the diet with $1.5 \%$ AmG, lower $(\mathrm{P}<0.05) \mathrm{DWG}$, as compared to those fed the positive control diet (Table 2). During the period of 21 to 42 days of age, the piglets fed the diet containing $1.0 \% \quad \mathrm{AmG}$ presented, in absolute values, a $21.7 \%$ increase in DWG as compared to fed the diet containing plasma.

Average daily feed intake (DFI) during the period of 21 to 28 days of age was higher for the treatment containing $1.0 \%$ AmG and lower $(\mathrm{P}<0.05)$ for the diet with $1.5 \%$ AmG as compared to the positive control diet. During the period of 21 to 42 days of age, the piglets fed the diet containing $1.5 \%$ AmG presented, in absolute values, 9.5\% DFI reduction relative to those fed the diet containing plasma.

Table 2. Average values to daily weight gain, average daily feed intake and feed conversion ratio of piglets during the periods of 21 to 28 and 21 to 42 days of age, as a function of the experimental diets

\begin{tabular}{|c|c|c|c|c|c|c|c|}
\hline \multirow[b]{2}{*}{ Period, days ${ }^{2}$} & \multicolumn{5}{|c|}{ Experimental diets $^{1}$} & \multirow[b]{2}{*}{ Mean } & \multirow{2}{*}{$\begin{array}{l}\mathrm{CV} \\
(\%)\end{array}$} \\
\hline & $\begin{array}{l}{ }^{\mathrm{T}} \text { Negative } \\
\text { control }\end{array}$ & $\begin{array}{l}0.5 \% \\
\text { AmG }\end{array}$ & $\begin{array}{l}1.0 \% \\
\text { AmG }\end{array}$ & $\begin{array}{l}1.5 \% \\
\text { AmG }\end{array}$ & $\begin{array}{l}\text { Positive } \\
\text { control }\end{array}$ & & \\
\hline \multicolumn{8}{|c|}{ Daily weight gain, g (DWG) } \\
\hline $21-28 Q_{1}$ & 74 & 97 & $133 *$ & $52 *$ & 79 & 87 & 47.8 \\
\hline $21-42 Q_{1}$ & 307 & 356 & 365 & 300 & 322 & 330 & 15.5 \\
\hline \multicolumn{8}{|c|}{ Average daily feed intake, g (DFI) } \\
\hline $21-28 Q_{1}$ & 147 & 183 & $222^{*}$ & $131 *$ & 173 & 171 & 32.3 \\
\hline $21-42 Q_{1}$ & 421 & 457 & 470 & 393 & 434 & 435 & 12.5 \\
\hline \multicolumn{8}{|c|}{ Feed conversion ratio $(\mathrm{FCR})$} \\
\hline $21-28 Q_{1}$ & 2.22 & 2.01 & $1.71 *$ & 2.55 & 2.43 & 2.18 & 17.8 \\
\hline $21-42 Q_{2}$ & 1.39 & $1.29 *$ & $1.28 *$ & 1.31 & 1.36 & 1.33 & 5.4 \\
\hline
\end{tabular}

${ }^{1}$ Means in the same row followed by an asterisk $(*)$ are different from the positive control treatment by Test of Dunnett.

${ }^{2} \mathrm{Q}_{1}=$ quadratic effect $(\mathrm{P}<0.01) ; \mathrm{Q}_{2}=$ quadratic effect $(\mathrm{P}<0.05)$

During the period of 21 to 28 days of age, the piglets fed the diet with $1.0 \%$ AmG presented better $(\mathrm{P}<0.05)$ feed conversion ratio (FCR) and, during the period of 21 to 42 days of age, those fed the diets containing 0.5 and $1.0 \%$ 
Rev. Bras. Saúde Prod. Anim., Salvador, v.15, n.4, p.881-896 out./dez., 2014 http://www.rbspa.ufba.br ISSN 15199940

glutamine + glutamic acid had better FCR as compared to the piglets fed the positive control diet.

There was a quadratic effect $(\mathrm{P}<0.01)$ of the treatments on DWG during the periods of 21 to 28 and 21 to 42 days of age. As shown by the regression equations presented in Table 3, maximum DWG may be obtained with the addition of 0.72 and $0.74 \%$ glutamine + glutamic acid to the diets for the periods of 21 to 28 and 21 to 42 days of age, respectively.

Table 3. Glutamine + glutamic acid $(\mathrm{AmG})$ level estimates and their respective equations for the parameters daily weight gain (DWG), average daily feed intake (DFI) and feed conversion ratio (FCR), during the periods of 21 to 28 and 21 to 42 days of age

\begin{tabular}{lccrrr}
\hline $\begin{array}{l}\text { Dependent } \\
\text { Variables }\end{array}$ & $\begin{array}{c}\text { Point of } \\
\text { Maximum or } \\
\text { Minimum }\end{array}$ & Equations & $\mathrm{R}^{2}$ & $\begin{array}{r}\mathrm{CV} \\
(\%)\end{array}$ & $\mathrm{P}$ \\
\hline DWG (21-28) & 0.72 & $\mathrm{Y}=0.0671796+0.14985 \mathrm{x}-0.103591 \mathrm{x}^{2}$ & 77 & 46.94 & 0.0031 \\
DWG (21-42) & 0.74 & $\mathrm{Y}=0.304974+0.170187 \mathrm{x}-0.115040 \mathrm{x}^{2}$ & 98 & 19.52 & 0.0206 \\
\hline DFI (21-28) & 0.74 & $\mathrm{Y}=0.139833+0.189806-0.127659 \mathrm{x}^{2}$ & 82 & 31.60 & 0.0043 \\
DFI $(21-42)$ & 0.69 & $\mathrm{Y}=0.417581+0.155526 \mathrm{x}-0.113280 \mathrm{x}^{2}$ & 94 & 18.03 & 0.0458 \\
\hline FCR $(21-28)$ & 0.68 & $\mathrm{Y}=2.2824-1.43281 \mathrm{x}+1.04643 \mathrm{x}^{2}$ & 80 & 20.36 & 0.0037 \\
FCR $(21-42)$ & 0.93 & $\mathrm{Y}=1.38282-0.230759 \mathrm{x}+0.123607 \mathrm{x}^{2}$ & 98 & 4.92 & 0.0148 \\
\hline
\end{tabular}

There was a quadratic effect $(\mathrm{P}<0.01)$ on DFI during the periods of 21 to 28 and 21 to 42 days of age. Based on the regression equations, the highest DFI can be obtaining by adding 0.74 and $0.69 \%$ AmG to the diets in the periods of 21 to 28 and 21 to 42 days of age, respectively.

There was a quadratic effect $(\mathrm{P}<0.01)$ on FCR during the periods of 21 to 28 and 21 to 42 days of age $(\mathrm{P}<0.05)$. According to the regression equations, the best FCR can be obtained by adding 0.68 and $0.93 \%$ AmG to the diets during the periods of 21 to 28 and 21 to 42 days of age, respectively.

Yi et al. (2005) did not observe any effect of glutamine (2\%) dietary supplementation on the performance of piglets weaned at 17 days of age when no immune challenge was present. The best response to glutamine supplementation was obtained when the piglets were challenged with Escherichia coli. Liu \& Jian (1999) found that the supplementation of both glutamine (Gln) and glutamate (Glu) improved the live performance of weaned piglets. In according to Tucci et al. (2011b), the employment of glutamine in the diet was not effective to influence the performance of piglets in the weaning process.

Abreu et al. (2010) did not observe any improvement in the performance of piglets during the first two weeks after weaning when glutamine was individually included in the diet, and suggested that the low health challenge during the experimental period may explain the observed lack of glutamine effects. However, during the total experimental period (21 to 42 days of age), those authors verified that the 
piglets fed nucleotides, $2.0 \%$ porcine plasma, $4.0 \%$ porcine plasma and porcine plasma + glutamine presented higher feed intake. The best daily weight gain responses were obtained by the piglets fed $2.0 \%$ porcine plasma and porcine plasma + glutamine as compared to those fed the control diet. The experimental diets influenced $(\mathrm{P}<0.05)$ feed conversion ratio, which was better in the piglets fed glutamine, $2.0 \%$ porcine plasma and porcine plasma + nucleotides.

Lackeyram et al. (2001) reported that the supplementation of $0.8 \%$ glutamine to diets based on corn and soybean meal increased body weight gain, small intestine weight, and the growth of other viscera in piglets submitted to early weaning at 10 days of age.

Molino et al. (2012) and Xiao et al. (2012) verified significant effects in the weight gain of piglets weaned at 21 days of age and supplemented with, respectively, $0.8 \%$ of glutamine and $21 \%$ of crude protein (CP); $1.0 \%$ of glutamine and $21.5 \%$ of crude protein (CP). These data denoted the importance of aminoacids to the initial phase of the animal development, since the animals in this phase require higher quantity of nutrients (CALSON et al., 2005).
In the same way, Shan et al. (2012), evaluating the effect of the inclusion of $1.0 \%$ of glutamine to piglets weaned at 28 days at age do not observed difference in the parameters of performance, incidence of diarrhea and intestinal morphology.

Lescano et al. (2013) evaluated the inclusion of a commercial product that contains glutamic acid more glutamine $(0 ; 0,4 ; 0,8$ e $1,2 \%)$ in a complete diet (corn, soybean meal, blood plasma and milk products) upon the performance of piglets in the range from 18 up to 46 days of age and intestinal morphology of piglets in the range from 18 up to 25 days of age. It was observed linear improvement in the daily feed intake and feed conversion and quadratic effect to final corporal weight, total weight gain and daily weight gain of the piglets, suggesting the best level of glutamic acid + glutamine $0.8 \%$.

During the period of 21 to 28 days of age, the piglets fed the diet containing $1.0 \%$ AmG presented lower $(\mathrm{P}<0.05)$ diarrhea score, whereas those in the negative control group had higher $(\mathrm{P}<0.05)$ incidence of diarrhea as compared to those fed the positive control diet (Table 4).

Table 4. Average values to diarrhea score during the periods of 21 to 28,28 to 35 and 35 to 42 days of age, as a function of the experimental diets

\begin{tabular}{|c|c|c|c|c|c|c|c|}
\hline \multirow[b]{2}{*}{ Period, days } & \multicolumn{5}{|c|}{ Experimental diets $^{1}$} & \multirow[b]{2}{*}{ Mean } & \multirow[b]{2}{*}{$\begin{array}{l}\text { CV } \\
(\%)\end{array}$} \\
\hline & $\begin{array}{l}{ }^{1} \text { Negative } \\
\text { control }\end{array}$ & $\begin{array}{l}0.5 \% \\
\mathrm{AmG}\end{array}$ & $\begin{array}{l}1.0 \% \\
\mathrm{AmG}\end{array}$ & $\begin{array}{l}1.5 \% \\
\mathrm{AmG}\end{array}$ & $\begin{array}{l}\text { Positive } \\
\text { control }\end{array}$ & & \\
\hline $21-28$ & $3.07 *$ & 2.93 & $2.46^{*}$ & 2.77 & 2.80 & 2.81 & 11.0 \\
\hline $\begin{array}{l}28-35 \\
35-42\end{array}$ & $\begin{array}{l}2.37 \\
2.05\end{array}$ & $\begin{array}{l}2.27 \\
2.07\end{array}$ & $\begin{array}{l}2.15 \\
1.92\end{array}$ & $\begin{array}{l}2.17 \\
2.06\end{array}$ & $\begin{array}{l}2.21 \\
2.08\end{array}$ & $\begin{array}{l}2.23 \\
2.04\end{array}$ & $\begin{array}{l}9.7 \\
8.1\end{array}$ \\
\hline
\end{tabular}

${ }^{\mathrm{T}}$ Means in the same row followed by an asterisk $(*)$ are different from the positive control treatment by Test of Dunnett. 
In piglets exposed at weaning to moderate E. coli infection, the supplementation of $4 \%$ glutamine exerted beneficial effects by maintaining normal intracellular glutamine concentration in the muscles, alleviating the detrimental effects of endotoxins on the permeability of the digestive tract (DUGAN \& McBURNEY, 1995). Glutamine reduces diarrhea in E. coli challenged animals because the adherence of that microorganism to the intestinal brush border is partially inhibited by residues of $\mathrm{N}$-acetylglucosamine and $\mathrm{N}$-acetylgalactosamine, which as synthesized from glutamine (REEDS \& BURRIN, 2001) and are components of mucin. Indeed, Lima et al. (2009) claim that the gastrointestinal dysfunctions are usually of multifactorial origin, predominanting the factors of nutritional, microbiological and environmental characteristics.

Diets influenced $(\mathrm{P}<0.05)$ intestinal villus height $(\mathrm{VH})$, with the piglets fed the diet containing $0.5 \%$ glutamine + glutamic acid presenting higher $\mathrm{VH}$ at 42 days of age, as compared to those consuming the positive control diet (Table 5).

There was a quadratic effect $(\mathrm{P}<0.05)$ of AmG supplementation on average crypt depth (CD) in the duodenum of 28-d-old piglets and in the jejunum at 42 days of age. Piglets fed the diets with $0, \quad 0.5$ and $1.5 \%$ AmG presented $(\mathrm{P}>0.05) \mathrm{CD}$ in the ileum relative to those consuming the diet with $1.0 \%$ AmG and the positive control diet. There was a quadratic effect $(\mathrm{P}<0.05)$ of AmG supplementation on villus:crypt ratio (VCR) in the duodenum and jejunum of 28-d-old piglets, and a linear effect when piglets were 42 days old. VCR increased in the duodenum and in general in the small intestine of the piglets fed 0.5 and $1.0 \% \mathrm{AmG}$, as well as in the jejunum of 28-d-old piglets fed the diet with $1.0 \%$ AmG inclusion.

$\mathrm{VH}$ and $\mathrm{CD}$ are influenced by several factors, including age, weaning stress, feed quality and quantity, feed intake, diarrhea, etc. the lower CD obtained in the $1.0 \%$ AmG treatment may be due to the better intestinal mucosa integrity, as the piglets in this treatment presented lower incidence of diarrhea. Higher CD was observed in the treatments presenting higher diarrhea scores due to increase in cell production caused by processes that increase intestinal sloughing.

Abreu et al. (2010) did not observe any influence of the dietary inclusion of glutamine, nucleotides or plasma on the intestinal morphology of weaning piglets. Similar results were obtained by Jiang et al. (2000), who worked with piglets weaned at 14 days of age and also did not observed any effects of plasma protein on villus height or crypt depth in the ileum and jejunum. The dietary inclusion of $1.0 \%$ L-glutamine also did not affect villi height of piglets weaned at 18 days of age in the study carried out by Kitt et al. (2002). However, Liu et al. (2002), studying the effect of dietary L-glutamine at the same level as that used in the present study $(1.0 \%)$, found that there was an improvement in villi height in the duodenum and jejunum of piglets only 7 days post-weaning, but not 14 days post-weaning. Wu et al. (1996) also observed that the addition of $1 \% \mathrm{~L}$ glutamine in the diet of piglets from 7 to 28 days of age improved intestinal mucosa integrity, preventing part of the deleterious effects of weaning on intestinal morphology. 
Rev. Bras. Saúde Prod. Anim., Salvador, v.15, n.4, p.881-896 out./dez., 2014 http://www.rbspa.ufba.br ISSN 15199940

Table 5. Average values to Villus height, crypt depth and villus to crypt ratio in each small intestine regions of piglets of 28,35 and 42 days of age, as a function of the experimental diets



${ }^{\mathrm{T}}$ Means in the same row followed by an asterisk $(*)$ are different from the positive control treatment by Test of Dunnett.

${ }^{2} \mathrm{~L}_{1}=$ linear effect $(\mathrm{P}<0.05) ; \mathrm{L}_{2}=$ Linear effect $(\mathrm{P}<0.10) ; \mathrm{Q}_{1}=$ Quadratic effect $(\mathrm{P}<0.01) ; \mathrm{Q}_{2}=$ Quadratic effect $(\mathrm{P}<0.05) ; \mathrm{Q}_{3}=$ Quadratic effect $(\mathrm{P}<0.06)$. 
Rev. Bras. Saúde Prod. Anim., Salvador, v.15, n.4, p.881-896 out./dez., 2014 http://www.rbspa.ufba.br ISSN 15199940

Hsu et al. (2010) observed increase in the villus height in the duodenum and jejunum and higher increase in the absorptive capability of xylose of piglets weaned at 14 days, supplemented with $1.0 \%$ and $2.0 \%$ of glutamine in relation to the animals without any supplementation.

In aggrement with Tucci et al. (2011a), the utilization of glutamine was not efficient to avoid the reduction in the villus height in the small intestine in the piglets submitted to the weaning process. However, the addition of glutamine in the basic diet increased the density of the jejunum villus at seventh day after the weaning process.

As the gastrointestinal tract of piglets is still immature at the time of weaning, and its development is essential to allow the animals to express their full genetic potential, a possible anabolic effect of glutamine and glutamate on digestive organs could enhance their functions, consequently improving nutrient digestion and absorption during that period.

Despite being considered a nonessential amino acid, recent studies demonstrated that endogenous glutamine reserves and synthesis capacity may not be sufficient to supply body needs during long stress periods, hyper-catabolic conditions, or long fasting periods (WATFORD et al., 2011). Due to the stress to which piglets are submitted during weaning and their significant reduction in feed intake, their glutamine reserves may be depleted, which may explain the positive response of carbon turnover in the viscera of the piglets fed the diet supplemented with glutamine.

There was a quadratic effect of the treatments on $\mathrm{CD}$ and villus:crypt ratio (VCR) in the duodenum and on VCR in the jejunum and intestinal regions in general in 28-d-old piglets, and on CD in the jejunum and small intestine in average of 42-d-old piglets (Table 6).

Table 6. Glutamine + glutamic acid (AmG) level estimates and their respective equations for villus height (VH), crypt depth (CD) and villus to crypt ration (VCR) in the duodenum (D), jejunum (J), ileum (I) and average of the three regions $(\mathrm{M})$ of the small intestine of piglets at 28 and 42 days of age

\begin{tabular}{lccccc}
\hline $\begin{array}{l}\text { Depedent } \\
\text { Variables }\end{array}$ & $\begin{array}{c}\text { Point of } \\
\text { Maximum or } \\
\text { Minimum }\end{array}$ & Equation & $\mathrm{R}^{2}$ & $\mathrm{CV}(\%)$ & $\mathrm{P}$ \\
\hline VH-I (28 days) & - & $\mathrm{Y}=329.038-25.4113 \mathrm{x}$ & 54 & 10.78 & 0.0368 \\
CD-D $(28$ days) & 0.88 & $\mathrm{Y}=300.019+125.701 \mathrm{x}-71.6033 \mathrm{x}^{2}$ & 100 & 12.62 & 0.0080 \\
VCR-D (28 days) & 0.85 & $\mathrm{Y}=1.08061+0.845504 \mathrm{x}-0.499615 \mathrm{x}^{2}$ & 98 & 19.37 & 0.0175 \\
VCR-J (28 days) & 0.84 & $\mathrm{Y}=1.08697+0.4907 \mathrm{x}-0.291561 \mathrm{x}^{2}$ & 56 & 14.98 & 0.0414 \\
VCR-M (28 days) & 0.79 & $\mathrm{Y}=1.16864+0.466704 \mathrm{x}-0.290653 \mathrm{x}^{2}$ & 82 & 9.19 & 0.0037 \\
\hline VH-D (42 days) & 0.83 & $\mathrm{Y}=394.850-159.849 \mathrm{x}+96.3533 \mathrm{x}^{2}$ & 52 & 13.56 & 0.0321 \\
VH-M (42 days) & 0.86 & $\mathrm{Y}=374.138+85.0652 \mathrm{x}-49.5561 \mathrm{x}^{2}$ & 79 & 8.76 & 0.0460 \\
CD-J (42 days) & 0.68 & $\mathrm{Y}=268.148-86.1327 \mathrm{x}-64.0467 \mathrm{x}^{2}$ & 95 & 9.41 & 0.0041 \\
VCR-J (42 days) & - & $\mathrm{Y}=1.32755+0.140665 \mathrm{x}$ & 82 & 14.36 & 0.0399 \\
VCR-M (42 days) & - & $\mathrm{Y}=1.30439+0.0845522 \mathrm{x}$ & 95 & 9.57 & 0.0641 \\
\hline
\end{tabular}


Ewtushik et al. (2000) reported that a diet supplemented with L-glutamic acid prevented villus atrophy in the duodenum induced by weaning of piglets submitted to early weaning as compared to a conventional diet and a diet with polyamines. However, the L-glutamic acid inclusion level was much higher $(6.51 \%)$ that the usual supplementation levels. Liu et al. (2002) found that, as compared to a control diet based on cornsoybeans-milk whey, the supply of diets supplemented with $1 \%$ L-glutamine or $1 \%$ L-glutamic acid to piglets weaned at 28 days of age prevented jejunum atrophy during the first post-weaning week, and improve D-xylose absorption capacity by the intestine on days 7 and 14 after weaning. As compared to the piglets fed the control diet or supplemented with $1 \%$ L-glutamine, the supply of $1 \%$ Lglutamic acid resulted in higher villus height at the end of the jejunum 14 days post-weaning and higher RNA concentration in skeletal muscles 7 days post-weaning.

Caldara et al. (2010) found that the supplementation of $1 \%$ L-glutamine in weaned piglet diets accelerated carbon turnover in the intestinal mucosa, indicating a positive response in the process mucosal turnover and that the capacity of adaptation of piglets to weaning presents individual variation.

There was no influence of the dietary treatments $(\mathrm{P}>0.05)$ on carcass yield or absolute and relative liver weights (Table 7). On the other hand, piglets fed $0.5,1.0$ and $1.5 \%$ AmG presented lower $(\mathrm{P}<0.05)$ kidney relative weight at 28 days of age, and those fed $1.0 \% \mathrm{AmG}$ had higher $(\mathrm{P}<0.05)$ absolute kidney weight $(\mathrm{P}<0.05)$ at 35 days of age. At 42 days, piglets fed the diets containing 0.5 and $1.0 \%$ AmG presented higher $(\mathrm{P}<0.05)$ absolute small intestine weight.
Several authors observed increase in digestive organ weights of pigs as a function of feedstuffs, particularly in feeds containing high soybean levels (TEIXEIRA et al., 2003). Perhaps the inclusion levels of soybeans in the experimental diets were not sufficient to promote the effects detected by other authors.

There was no effect $(\mathrm{P}>0.05)$ of $\mathrm{AmG}$ dietary inclusion on the $\mathrm{pH}$ of the stomach content in the cardia or in the duodenal content of the piglets at all evaluated ages as compared to the diet containing plasma (Table 8). However, the dietary inclusion of $0.5,1.0$ and $1.5 \% \mathrm{AmG}$ reduced the $\mathrm{pH}$ of the ileal content of 28 -d-old piglets. When the diets contained $0,0.5$ or $1.0 \% \mathrm{AmG}, \mathrm{pH}$ of the stomach content in the pylorus was reduced in 42-d-old piglets.

The $\mathrm{pH}$ measured in the stomach for the different feeds and at different ages is within the optimal range for pepsin action (2 to 4), as proposed by Passos Junior (1997). However, small intestine $\mathrm{pH}$ values were lower than the optimal $\mathrm{pH}$ range of 7.8 to 8.1 , for the action of trypsin and chymotrypsin. Moreover, it was observed that stomach $\mathrm{pH}$ decreased as animals aged, due to the piglets increasing capacity of adjusting gastric $\mathrm{pH}$ by the secretion of hydrochloric acid by the parietal cells.

The measurement of the intestinal $\mathrm{pH}$ value was developed to demonstrate the effect of the treatments regarding the indicators of intestinal health, since a high $\mathrm{pH}$ can favor the colonization of villus with enterotoxic bacteria, such as Escherichia coli, promoting symptoms as diarrhea. On the other hand, low $\mathrm{pH}$ can favor the development of the nonpathogenic bacteria and/or to inhibit the development of pathogenic bacteria (WU et al., 2011). 
Table 7. Average values to Carcass yield and absolute and relative liver and kidney weights of piglets of 28, 35 and 42 days of age, as a function of the experimental diets

\begin{tabular}{|c|c|c|c|c|c|c|c|}
\hline \multirow{2}{*}{ Age (days) } & \multicolumn{5}{|c|}{ Experimental diets $^{1}$} & \multirow{2}{*}{ Mean } & \multirow{2}{*}{$\mathrm{CV}(\%)$} \\
\hline & ${ }^{\mathrm{T}}$ Negative control & $0.5 \% \mathrm{AmG}$ & $1.0 \% \mathrm{AmG}$ & $1.5 \% \mathrm{AmG}$ & Positive control & & \\
\hline \multicolumn{8}{|c|}{ Carcass yield, $\%$} \\
\hline 28 & 69.88 & 71.90 & 71.36 & 68.26 & 70.91 & 70.46 & 5.0 \\
\hline 35 & 67.79 & 70.43 & 69.61 & 70.08 & 67.94 & 69.17 & 4.2 \\
\hline 42 & 69.05 & 68.44 & 70.41 & 69.01 & 69.80 & 69.34 & 3.3 \\
\hline \multicolumn{8}{|c|}{ Absolute liver weight, $\mathrm{g}$} \\
\hline 28 & 134 & 137 & 139 & 127 & 127 & 133 & 16.1 \\
\hline 35 & 215 & 227 & 273 & 215 & 258 & 238 & 20.5 \\
\hline 42 & 386 & 390 & 418 & 366 & 371 & 386 & 15.1 \\
\hline \multicolumn{8}{|c|}{ Relative liver weight, $\%$} \\
\hline 28 & 2.53 & 2.57 & 2.57 & 2.54 & 2.49 & 2.54 & 12.6 \\
\hline 35 & 2.85 & 2.97 & 2.95 & 3.24 & 3.27 & 3.06 & 10.3 \\
\hline 42 & 3.21 & 3.17 & 3.08 & 3.31 & 3.24 & 3.20 & 8.3 \\
\hline \multicolumn{8}{|c|}{ Absolute kidney weight, g } \\
\hline 28 & 30 & 28 & 27 & 26 & 32 & 29 & 21.8 \\
\hline 35 & 41 & 40 & $51 *$ & 37 & 42 & 42 & 18.4 \\
\hline 42 & 65 & 70 & 71 & 62 & 64 & 66 & 14.0 \\
\hline \multicolumn{8}{|c|}{ Relative kidney weight, \% } \\
\hline 28 & 0.57 & $0.52 *$ & $0.50^{*}$ & $0.55^{*}$ & 0.62 & 0.55 & 11.3 \\
\hline 35 & 0.54 & 0.52 & 0.55 & 0.54 & 0.56 & 0.54 & 10.2 \\
\hline 42 & 0.54 & 0.56 & 0.52 & 0.56 & 0.58 & 0.55 & 12.0 \\
\hline \multicolumn{8}{|c|}{ Absolute small intestine weight, $g$} \\
\hline 28 & 363 & 360 & 342 & 367 & 330 & 352 & 30.8 \\
\hline 35 & 575 & 529 & 665 & 593 & 608 & 594 & 22.2 \\
\hline 42 & 829 & $889 *$ & $928^{*}$ & 803 & 787 & 847 & 10.4 \\
\hline \multicolumn{8}{|c|}{ Relative small intestine weight, $\%$} \\
\hline 28 & 6.87 & 6.99 & 6.26 & 7.16 & 6.47 & 6.75 & 22.6 \\
\hline 35 & 7.88 & 7.35 & 7.20 & 8.88 & 8.28 & 7.92 & 21.1 \\
\hline 42 & 6.96 & 7.40 & 6.85 & 7.32 & 7.32 & 7.17 & 14.9 \\
\hline
\end{tabular}

${ }^{\mathrm{T}}$ Means in the same row followed by an asterisk $(*)$ are different from the positive control treatment by Test of Dunnet. 
Rev. Bras. Saúde Prod. Anim., Salvador, v.15, n.4, p.881-896 out./dez., 2014 http://www.rbspa.ufba.br ISSN 15199940

Table 8. Average values to $\mathrm{pH}$ of the stomach content (cardia and pylorus) and small intestine content (duodenum and ileum) of piglets at 28, 35 and 42 days of age, as a function of the experimental diets

\begin{tabular}{|c|c|c|c|c|c|c|c|}
\hline \multirow{3}{*}{ Age (days) } & \multicolumn{5}{|c|}{ Experimental diets ${ }^{1}$} & \multirow{3}{*}{ Mean } & \multirow{3}{*}{$\begin{array}{l}\text { CV } \\
(\%)\end{array}$} \\
\hline & ${ }^{1}$ Negative & $0.5 \%$ & $1.0 \%$ & $1.5 \%$ & Positive & & \\
\hline & control & $\mathrm{AmG}$ & $\mathrm{AmG}$ & $\mathrm{AmG}$ & control & & \\
\hline 28 & 4.18 & 4.13 & 4.22 & 4.14 & 3.71 & 4.08 & 13.8 \\
\hline 35 & 3.59 & 3.43 & 3.82 & 3.93 & 3.51 & 3.66 & 17.2 \\
\hline 42 & 3.35 & 3.50 & 3.46 & 3.65 & 3.43 & 3.48 & 12.6 \\
\hline \multicolumn{8}{|c|}{ Stomach pH (pylorus) } \\
\hline 28 & 2.51 & 2.55 & 2.85 & 2.48 & 2.15 & 2.51 & 22.8 \\
\hline 35 & 3.26 & 3.10 & 3.26 & 2.89 & 3.22 & 3.15 & 18.0 \\
\hline 42 & $3.01 *$ & $3.25 *$ & $2.98 *$ & 3.57 & 3.54 & 3.27 & 13.6 \\
\hline \multicolumn{8}{|c|}{ Small intestine $\mathrm{pH}$ (duodenum) } \\
\hline 28 & 6.25 & 6.04 & 5.90 & 5.70 & 5.59 & 5.90 & 8.3 \\
\hline 35 & 5.65 & 5.48 & 5.42 & 5.72 & 5.64 & 5.58 & 10.7 \\
\hline 42 & 5.37 & 5.26 & 5.64 & 5.38 & 5.10 & 5.35 & 10.5 \\
\hline \multicolumn{8}{|c|}{ Small intestine $\mathrm{pH}$ (ileum) } \\
\hline 28 & 6.82 & $6.66^{*}$ & $6.69 *$ & $6.56^{*}$ & 6.84 & 6.71 & 2.2 \\
\hline 35 & 6.94 & 6.67 & 6.79 & 6.59 & 6.66 & 6.73 & 4.6 \\
\hline 42 & 6.73 & 6.59 & 6.75 & 6.92 & 6.77 & 6.75 & 4.4 \\
\hline
\end{tabular}

${ }^{\mathrm{T}}$ Means in the same row followed by an asterisk (*) are different from the positive control treatment by Test of Dunnett.

The dietary supplementation of $1 \%$ glutamine associated to glutamic acid improves the live performance and gastrointestinal morphophysiology of piglets weaned at 21 days of age.

\section{ACKNOWLEDGEMENTS}

The authors thank Universidade Federal de Viçosa for supplying the facilities and equipment, and Ajinomoto do Brasil for donating the amino acids used in the experimental feeds.

\section{REFERENCES}

ABREU, M.L.T.; DONZELE, J.L.; SARAIVA, A.; OLIVEIRA, R.F.M.; FORTES, E.L.; GRANA, G.L.

Glutamina, nucleotídeos e plasma suíno em rações para leitões desmamados.

Revista Brasileira de Zootecnia, v.39, n.3, p.520-525, 2010.

ABREU, M.L.T.; DONZELE, J.L. Glutamina na nutrição de leitões. In: SIMPÓSIO SOBRE MANEJO E NUTRIÇÃO DE AVES E SUÍNOS, 5., 2008, Cascavel, PR. Anais... Cascavel, PR: CBNA, 2008. p.170.

BIKKER, P.; VAN DIJK, A.J.;

DIRKZWAGER, A.; FLEDDERUS, J.; UBBINK-BLANKSMA, M.; BEYNEN, A.C. The influence of diet composition and anti-microbial growth promoter on the growth response of weaned piglets to spray dried animal plasma. Livestock Production Science, v.86, n.1-3, p.201-208, 2004.

CALDARA, F.R.; DUCATTI, C.;

BERTO, D.A.; DENADAI, J.C.;

GARCIA, R.G.; FERREIRA, V.M.O.S. 
Rev. Bras. Saúde Prod. Anim., Salvador, v.15, n.4, p.881-896 out./dez., 2014 http://www.rbspa.ufba.br ISSN 15199940

Glutamina e turnover do carbono da mucosa intestinal de leitões desmamados. Revista Brasileira de Zootecnia, v.39, n.12, p.2664-2669, 2010 .

CALSON, M.S., VEUM, T.L. AND TURK, J.R. Effects of yeast extract versus animal plasma in weanling pig diets on growth performance and intestinal morphology. Journal of Swine Health and Production. v.13, n.4, p.204-209, 2005.

CURI, R.; LAGRANHA, C.J.; DOI, S.Q.; SELLITTI, D.F.; PROCOPIO, J.; PITHON-CURI, T.C.; CORLESS, M.; NEWSHOLME, P. Molecular mechanisms of glutamine action.

Journal of Cellular Physiology, v.204, p.392-401, 2005.

DUGAN, M.E.R., MCBURNEY, M.I. Luminal glutamine perfusion alters endotoxin-related changes in ileal permeability of the piglet. Journal of Parenteral and Enteral Nutrition, v.19, p.83-87, 1995.

EWTUSHIK, A.L.; BERTOLO, R.F.P.; BALL, R.O. Intestinal development of early-weaned piglets receiving diets supplemented with selected amino acids or polyamines. Canadian Journal of Animal Science, v.80, p.653-662, 2000.

HSU, C.B.; HUANG, H.J.; WANG, C.H.; YEN, H.T; YU, B. The effect of glutamine supplement on small intestinal morphology and xylose absorptive ability of weaned piglets. African Journal of Biotechnology, v.9, n.41, p.7003-7008, 2010.

JIANG, R.; CHANG, X.; STOLL, B.; FAN, M. Z; ARTHINGTON, J.; WEAVER, E.; CAMPBELL, J.; BURRIN, D. Dietary plasma protein reduces small intestinal growth and lamina propria cell density in early weaned pigs. Journal of Nutrition, v.130, n.1, p.21-26, 2000.

KITT, S.J.; MILLER, P.S.; LEWIS, A.J. et al. Effects of glutamine on growth performance and small intestine villus height in weanling pigs.

Nebraska Swine Report, p.29-32, 2002.

LACKEYRAM, D.; YUE, X.; FAN, M.Z. Effects of dietary supplementation of crystalline L-glutamine on the gastrointestinal tract and whole body growth in early-weaned piglets fed corn and soybean meal-based diets. Journal Animal Science, v.79, p. 11, 2001.

LESCANO, D.; ALBINO, L.;

HANNAS, M.; SALGUEIRO, S.; KUTSCHENKO, M.; NOGUEIRA, E.; ROSTAGNO, H. Evaluation of dietary glutamic acid plus glutamine levels on the growth performance of piglets.

Journal of Animal Science, v. 91, p.107, 2013. E-Suppl. 2 /Journal Dairy of Science, v.96, E-Suppl. 1, T307.

LIMA, G.J.M.M.; MORES, N.; SANCHES, R.L. As diarréias nutricionais na suinocultura. Acta Scientiae Veterinariae, v.37, p.17-30, 2009. Supl. 1.

LIU, T.; PENG, J. XIONG, Y.; ZHOU, S.; CHENG, X. Effects of dietary glutamine and glutamate supplementation on small intestinal structure, active absorption and DNA, RNA concentrations in skeletal muscle tissue of weaned piglets during d 28 to 42 of age. Asian-Australian Journal of Animal Science, v.16, n. 2, p.238242, 2002. 
Rev. Bras. Saúde Prod. Anim., Salvador, v.15, n.4, p.881-896 out./dez., 2014 http://www.rbspa.ufba.br ISSN 15199940

LIU, T.; JIAN, P. Effects of glutamine and glutamate on the performance of early-weaned piglets. Journal of Huazhong Agricultural University, v.18, n.5. p.457-460, 1999.

MOLINO, J.P.; DONZELE, J.L.; OLIVEIRA, R.F.M.; SARAIVA, A.; HAESE, D.; FORTES, E.I. L-glutamine and L-glutamate in diets with different lactose levels for piglets weaned at 21 days of age. Revista Brasileira de Zootecnia, v.41, n.1, p.98-105, 2012.

PIVA, A.; BACH KNUDSEN, K.E.; LINDBERG, J.E. Glutamine in gut metabolism. In: PIVA, A.; BACH KNUDSEN, K.E.; LINDBERG, J.E. Gut environment of pigs. Nottingham: Nottingham University Press, 2001. 260p.

REEDS, P.J.; BURRIN, D.G. Glutamine and the bowel. Journal of Nutrition, v.131, p.2505S-2508S, 2001.

ROSTAGNO, H.S.; ALBINO, L.F.T.; DONZELE, J.L.; GOMES, P.C.; OLIVEIRA, R.F.; LOPES, D.C.; FERREIRA, A.S.; BARRETO, S.L.T.

Tabelas brasileiras para aves $\mathrm{e}$ suínos: composição de alimentos e exigências nutricionais. Viçosa: Universidade Federal de Viçosa, 2005. $186 \mathrm{p}$.

SHAN, Y.; SHAN, A.; LI, J.; ZHOU, C. Dietary supplementation of arginine and glutamine enhances the growth and intestinal mucosa development of weaned piglets. Livestock Science, v.150, p.369-373, 2012.

TEIXEIRA, A.O.; LOPES, D. C.; FERREIRA, A. S.; DONZELE, J. L.; COSTA, I. R. S.; OLIVEIRA, R. F. M. DE; FERREIRA, VANUSA P. A.;
SOUZA, A. V. C. de. Efeito de Dietas Simples e Complexas sobre a Morfofisiologia Gastrintestinal de Leitões até 35 Dias de Idade. Revista Brasileira de Zootecnia, v.32, n.4, p.926-934, 2003.

TUCCI, F.M.; THOMAZ, M.C.; NAKAGHI, L.S.O.; HANNAS, M.I.; SCANDOLERA, A.J.; BUDIÑO, F.E.L. Efeito da adição de agentes tróficos na dieta de leitões desmamados sobre a estrutura e ultraestrutura do intestino delgado e sobre o desempenho. Arquivo Brasileiro de Medicina Veterinária e Zootecnia, v.63, n.4, p.931-940, 2011a.

TUCCI, F.M.; THOMAZ, M.C.; PIZAURO JÚNIOR, J.M.; HANNAS, M.I; SCANDOLERA, A.J.; BUDIÑO, F.E.L. Agentes tróficos na dieta de leitões desmamados sobre a atividade das enzimas digestivas e o desempenho.

Brazilian Journal of Veterinary Research and Animal Science, v.48, n.4, p.289-298, 2011 b.

WATFORD, M.; KUTSCHENKO, M.; NOGUEIRA, E.T. Optimal dietary glutamine for growth and development. Revista Brasileira de Zootecnia, v.40, p.402-408, 2011.

WU, G.; BAZER, F.W.; JOHNSON, G.A.; KNABE, D. A.; BURGHARDT, R. C.; SPENCER,T. E.; LI, X. L.; WANG, J. J. TRIENNIAL GROWTH SYMPOSIUM: Important roles for 1glutamine in swine nutrition and production. Journal of Animal Science, v.89, n.7, p.2017-2030, 2011.

WU, G.; MEIER, S.A.; KNABE, D.A. Dietary glutamine supplementation prevents jejunal atrophy in weaned pigs. Journal of Nutrition, v.126, p.25782584, 1996. 
XIAO, Ying-ping; WU, Tiang-xing;

HONG, Qi-hua; SUN, Jiang-ming;

CHEN, An-guo; YANG, Cai-mei; LI,

Xiao-yan. Response to weaning and

dietary L-glutamine supplementation:

metabolic analysis in piglets by gas

chromatography/mass spectrometry.

Journal of Zhejiang University -

Science B (Biomedicine \&

Biotechnology), v.13, n.7, p.567-578,

2012.

YI, G.F.; CARROLL, J.A.; ALLEE, G.L.; GAINES, A.M.; KENDALL,

D.C.; USRY, J.L.; TORIDE, Y.;

IZURU, S. Effect of glutamine and spray-dried plasma on growth performance, small intestinal morphology and immune responses of Escherichia coli k88+- challenged weaned pigs. Journal of Animal Science, v.83, n.3, p.634-643, 2005.

Data de recebimento: 17/02/2014

Data de aprovação: 20/10/2014 